\section{SOI: $1.1 /$ TAS DOI: $10.15863 /$ TAS International Scientific Journal Theoretical \& Applied Science}

p-ISSN: 2308-4944 (print) e-ISSN: 2409-0085 (online)

Year: $2018 \quad$ Issue: $03 \quad$ Volume: 59

Published: $30.03 .2018 \quad$ http://T-Science.org
Ya.S. Gryshchenko

$\mathrm{PhD}$ in Philology, Associate Professor, Department of the English Language of Technical Orientation № 1, National Technical University of Ukraine "Igor Sikorsky Kyiv Polytechnic Institute"

SECTION 29. Literature. Folklore. Translation Studies

\title{
THE NOTION OF MACROPHRASING IN TEXT LINGUISTICS
}

Abstract: The article deals with the overview of the peculiarities of understanding the notion of macrophrasing in text linguistics. Different approaches to the interpretation of the notion of phrasing are given. The description of the main aspects of macrophrasing in terms of the structure of the verse is provided.

Key words: macrophrasing, text linguistics, composition, image, context.

Language: English

Citation: Gryshchenko YS (2018) THE NOTION OF MACROPHRASING IN TEXT LINGUISTICS. ISJ Theoretical \& Applied Science, 03 (59): 160-163.

Soi: http://s-o-i.org/1.1/TAS-03-59-26 Doi: crossef https://dx.doi.org/10.15863/TAS.2018.03.59.26

\section{Introduction}

Structural linguistics as one of the most interesting areas of text linguistics in the field of the literary works analysis is a set of views on the language and methods of its study. It is based on the understanding of language as a sign system with clearly distinguished structural elements and a tendency to exact formal language description [12, 496]. The depth and surface text structures detection is possible within these scopes. However, it should be taken into consideration that there have been certain differences in the structure of poetry and any other literary text.

In prose, units of lower levels are included in units of such higher ones as phonemes that consist of distinctive features, e.g. syllables are divisible into phonemes, tacts - into syllables, colas - into tacts. It is had to be the same with meaningful forms: the words which are composed of morphemes, sentences - from words, supra-phrasal unities - from sentences. However, the poem, as the most important compositional unit that possesses usual and occasional semantics, has the ability to "cut" into parts the units of lower levels. The border of the verse often passes within the sentence, phrase, word or morpheme (sometimes within the tact or syllable). However, it can not be said that the verse is "composed" of them. The movement of a word, a morpheme or even a syllable from one line to another is just a rhythm modulator. Sound, intonation, syntactic, lexico-semantic language means are involved in the formation of the rhythm $[12,416]$. Thus, it is reasonable to say about the engaging of the voice in the process of cognitive study of the poetry, and this requires an appeal to the notion of text phrasing.

The purpose of our article is the overview of the notion of text phrasing in the field of text linguistics.

\section{Materials and Methods}

The Old Greek notion of the frazis "covered the language in the general sense, the construction of the language, and the personality of its exteriorization" [9, 72]. The notion of phrase, according to the Dictionary of foreign language words by I.V. Leochina and F.N. Petrova, is a complete turn of speech or a sentence [8, 700]. At the same time, according to V.N. Yartseva, the broader meaning of the phrase is given. A phrase is distinguished as the basic unit of speech expressing the complete idea, the content unity, the integrity of which is created by intonational means, as well as a certain syntactic structure $[12,558]$. The notion of phrasing can be found in the Dictionary of linguistic terms by O.S. Akhmanova, which is defined as the application of super-segmental phonetic means (pause, tempo, etc.) for expressive reading [1, 504]. Very similar definition of the phrase is given in the work by O.V. Aleksandrova and T.N. Shishkina's: "fragmentation is a use of suprasegmental phonetic means and a placement of pauses in the speech streaming chosen by the speaker" $[2,21]$.

Thus, we can observe the gradual narrowing of the framework of the notion of phrasing. We focus on the hermeneutical content of the notion of 
phrasing which is necessary to restore the completeness of understanding. In the article by N.P. Neborsina it is proved that the cognitive-poetic content of the category of phrasing that consists of: "1) the appearance of language (speech phenomenology); 2) formal language (rhetorical implementation); 3) generic comfort language (the choice of emotional and psychological colour)" [9, 74]. This interpretation of the phrasing is the most suitable for its study in terms of text linguistics and rhetorical hermeneutics.

As the example for the aforesaid statement the poem by T. Moore "A reflection at sea" is analysed $[5,20]$.

See how, beneath the moonbeam's smile,

You little billow heaves its breast,

And foams and sparkles for awhile, -

Then murmuring subsides to rest.

Thus man, the sport of bliss and care,

Rises on Time's eventful sea;

And, having swelled a moment there,

Thus melts into eternity.

The poem is divided into two stanzas, where the first stanza is practically entirely devoted to the sea (except for the comparison of the wave that arises, with the chest of man), and the second stanza is used for the description of the man. The author's distribution of the poem on the lines coincides with the rhetorical distribution of the poem in time of reading. The general idea of this poem is represented by the next lexemes: billow, man, eternity. The author of the poem associates the human "eternal" life (generation after generation) with the eternity of alternating waves in the sea. We can even speak about the concept of eternity, which is emphasized in the poem by the capital letter in the sixth line.

Literary work as a specific form of the existence of fiction has a systemic character. Significantly, the ideological and aesthetic systematicity is determined by the image structure of the work and the relations of interaction between different types of images [6].

Thus, we study the literary work in terms of its image structure. We understand images as certain verbal ones (tropes and various syntactic figures) and larger semantic units of the literary work, poetic images [7, 178], that include figures of people, animals (images-characters, narrators) and their natural (images-landscapes) or real-life (imagesinteriors) environment.

In terms of size and place in the work, three types of poetic images are distinguished: 1) microimage is the smallest elementary artistic value as the initial unit of figurative artistic thinking measurement, in which an artistically depicted a small particle of being exists (It can be expressed in one sentence, paragraph, or even a superphrasal unity); 2) macro-image, which is a hierarchically higher integral verbal-artistic value, the structure of which may include closely related, homogeneous micro-images; 3) mega-image is a system of macroimages (with their constituent components microforms) and individual micro-images that appear as separate art details and have their own functions in the literary work [6].

As an example of the aforesaid structure, we analyse William Wordsworth's poem "Gipsies" [11, 171].

Yet are they here the same unbroken knot Of human Beings, in the self-same spot!

Men, women, children, yea the frame

Of the whole spectacle the same!

Only their fire seems bolder, yielding light,

Now deep and red, the colouring of night;

That on their Gipsy-faces falls,

Their bed of straw and blanket-walls.

- Twelve hours, twelve bounteous hours are gone, while I

Have been a traveller under open sky,

Much witnessing of change and cheer,

Yet as I left I find them here!

The weary Sun betook himself to rest; -

Then issued Vesper from the fulgent west,

Outshining like a visible God

The glorious path in which he trod.

And now, ascending, after one dark hour

And one night's diminution of her power,

Behold the mighty Moon! this way

She looks as if at them - but they

Regard not her: - oh better wrong and strife

(By nature transient) than this torpid life;

Life which the very stars reprove

As on their silent tasks they move!

Yet, witness all that stirs in heaven or earth!

In scorn I speak not; - they are what their birth

And breeding suffer them to be;

Wild outcasts of society!

The mega-image in this poem is the Gypsies themselves; macro-images are men, women and children of gipsy, and micro-images are details of the description of the Gipsies themselves and their lifestyle. But such a clear division into images is not final and it does not have a general tendency that can be applied to any other poetic work.

It is also necessary to pay attention to the distribution of the context - the communicative environment and the environment of the text unit, which specifies its meaning within the general content of the text (the division on micro-context and macro-context). The first notion is understood as the minimal surrounding of the text unit. Macro-context refers to the communicative surrounding of a text unit, which allows one to define its function in the text as a whole [3, 91]. For example, let us take a sentence from the verse "Feelings of a Republican on the fall of Bonaparte" by Percy Bysshe Shelley: "I hated you, fallen into a tyrant!" $[10,10]$. 
Providing that the title of the poem is unknown we pay attention to the lexical unit "tyrant". If the context consists only of this sentence, then it is difficult to understand the meaning of this lexical unit in this verse. It is necessary to involve macrocontext and pay attention to the title and the full text of the verse. Then the reader can see that the lexical unit "tyrant" in this case is completely associated with Bonaparte.

Corresponding to the distribution of poetic images into macro- and micro-images, it is possible to extract and study the features of macrofragmentation of the verse. The notion of macrophrasing is much broader than just the notion of the phrasing of the verse. It includes both external and internal sides.

Let us consider the composition of the poem "Home-thoughts, from abroad" by Robert Browning [4].

Oh, to be in England

Now that April's there,

And whoever wakes in England

Sees, some morning, unaware, sheaf

That the lowest boughs and the brush-wood

Round the elm-tree bole are in tiny leaf,

While the chaffinch sings on the orchard bough

In England - now!

\section{II}

And after April, when May follows,

And the whitethroat builds, and all the swallows! hedge

Hark, where my blossomed pear-tree in the

Leans to the field and scatters on the clover

Blossoms and dewdrops - at the bent spray's edge over,

That's the wise thrush; he sings each song twice

Lest you should think he never could recapture

The first fine careless rapture! dew,

And though the fields look rough with hoary

All will be gay when noontide wakes anew

The buttercups, the little children's dower

- Far brighter than this gaudy melon-flower!

The verse is clearly divided into two stanzas, each one is numbered. There are four exclamation marks that tell us about the exalted spirit of the poem. The first stanza is written in the present time, and there is a gradual transition from the present to the future time in the second stanza. It shows the gradual awakening of England in the spring. The text of the verse depicts only two months of spring, but due to the smooth transition in the last four lines from the use of the present time to the future one, and then, in general, to the complete absence of a verb replacing the dash, it is possible to notice the following summer months, they have not yet come, but their appearance is predictable. Furthermore, the first and second stanzas are linked by a conjunction "and", which emphasizes the smooth transition from one month to another.

As for the architectonics of the verse, it is completely connected with the external structure and is expressed through certain stylistic figures and tropes. In the poem, we encounter such tropes as metaphor (hoary dew; wise thrush; ... when noontide wakes anew the buttercups ...), epithet (the lowest, tiny, careless, little, fine, gaudy) and comparison (fields look rough). Also, in the text of the poem, we encounter four exclamation marks that represent four rhetorical exclamations. In addition, in the verse the anaphora ("And after April, when May follows,// And the whitethroat builds, and all the swallows!") and ellipsis ("The buttercups, the little children's dower // - Far brighter than this gaudy melonflower!") are presented. It should be mentioned that these syntactic shapes and tropes express the inner side of the verse. These stylistic devices are used to express the peculiarities of the psychology and aesthetics of thinking of the poet.

\section{Conclusion}

Consequently, the external side (composition) of the verse is represented by the structural and grammatical features of the verse, while the internal one (architectonics) is verbalised by rhetorical, aesthetic and psychological peculiarities. Therefore, in order to understand any poem in its entirety, it is necessary to pay attention to the components of the external and internal sides of the poem, but first of all, one must understand the connection between them and the hermeneutical research of literary texts in general.

Thus, it should be concluded that phrasing is always individual, since the perception of the text is carried out by readers with different levels of knowledge, experience and various psychological differences; therefore, the perception of the text purpose of interpretation requires the intensification of all these individual characteristics and the continuous concentration of attention on the text as an object of interpretation.

The peculiarities of macrophrasing of the verse are closely dependant on the diversity of the composition and the architectonics, which will be the objects of the further investigations. 


\begin{tabular}{l|lr|ll|ll} 
& ISRA (India) & $=\mathbf{1 . 3 4 4}$ & SIS (USA) & $=\mathbf{0 . 9 1 2}$ & ICV (Poland) & $=\mathbf{6 . 6 3 0}$ \\
Impact Factor: & ISI (Dubai, UAE) $=\mathbf{0 . 8 2 9}$ & PUHL (Russia) $=\mathbf{0 . 2 0 7}$ & PIF (India) & $=\mathbf{1 . 9 4 0}$ \\
& GIIF (Australia) & $=\mathbf{0 . 5 6 4}$ & ESJI (KZ) & $=4.102$ & IBI (India) & $=\mathbf{4 . 2 6 0}$ \\
& JIF & $=\mathbf{1 . 5 0 0}$ & SJIF (Morocco) & $=2.031$ & & \\
\hline
\end{tabular}

\section{References:}

1. Ahmanova, O. (1969). Slovar lingvisticheskikh terminov. Moscow, USSR: Sovetskaya ehnciklopediya.

2. Aleksandrova, O., \& Shishkina, T. (1982). Frazirovka kak sintaktiko-stilisticheskaya problema. Voprosy yazykoznaniya , 21-27.

3. Barabanova, G. (2005). Metodika navchannya profesijno-oriyentovanogo chitannya $v$ nemovnomu VNZ. Kyiv, Ukraine: INKOS.

4. Browning, R. (1984). Home thoughts from abroad. S. King.

5. Campbell, F. (1824). Beauties of the British Poets: With Notices, Biographical and Critical (Vol. 1). R. Edwards.

6. Ivanishin, V. (2003). Piznannya literaturnogo tvoru. Drogobich, Ukraine: Vidrodzhennya.

7. Kviatkovskii, A. (1966). Poeticheskii slovar. Moscow, USSR: Sovetskaya ehnciklopediya.
8. Lyohin, V., \& Petrov, N. (1949). Slovar inostrannyh slov. Moscow, USSR: Izd-vo inostrannyh i nacionalnyh slovarej.

9. Neborsina, N. (2004). Germenevtika movlennya: frazuvannya yak kognitivnopoetichna kategoriya. Visnik Kiyivskogo nacionalnogo universitetu meni Tarasa Shevchenka. Inozemna filologiya, 71-74.

10. Shelley, P. B. (1975). Feelings of a Republican on the Fall of Bonaparte. The Complete Poetical Works of Percy Bysshe Shelley, 2, 10.

11. Wordsworth, W. (1854). The complete poetical works of William Wordsworth. Troutman \& Hayes.

12. Yartseva, V. (1990). Lingvisticheskii entsiklopedicheskii slovar. Moscow, Russia: Sovetskaya ehnciklopediya. 